\title{
The genetics of floral development differentiating two species of Mimulus (Scrophulariaceae)
}

\author{
CHARLES B. FENSTER*, PAMELA K. DIGGLE†, SPENCER C. H. BARRETT \& KERMIT \\ RITLAND \\ Department of Botany, University of Toronto, Toronto, Canada M5S 382
}

\begin{abstract}
Investigation of the developmental processes responsible for the evolution of the small-flowered, highly selfing Mimulus micranthus from its large-flowered, mixed-mating progenitor M. guttatus, revealed $M$. micranthus to have both a shorter duration and a higher rate of bud development. Hence flowers of $M$. micranthus can be considered as progenetic forms of $M$. guttatus. Genetic analysis of $\mathrm{F}_{1}, \mathrm{~F}_{2}$ and backcross generations derived from the cross $M$. micranthus $\times M$. guttatus provided no evidence for major gene control of development processes responsible for differentiating the two taxa. Furthermore, $F_{2}$ segregation patterns suggest that duration and rate of development may be genetically independent of one another. Hence, the evolution of small-flowered selfing taxa in Mimulus may reflect selection for rapid development.
\end{abstract}

Keywords: floral development, heterochrony, mating system, Mimulus.

\section{Introduction}

Changes in relative rates and timing of developmental processes among ancestral and derived species (i.e. heterochrony sensu de Beer, 1930, cited in Gould, 1988), have frequently been invoked as important developmental mechanisms accounting for the evolution of complex morphologies (Gould, 1977, 1988). The underlying appeal of using a developmental approach to understanding complex changes in morphology is that the evolution of morphology may be associated with relatively simple changes in rates and timing of development. The potential for heterochrony to play an important role in plants at both the macroevolutionary and microevolutionary scale has been recognized (Takhtajan, 1976; Guerrant, 1988; Diggle, 1992). In particular, the evolution of smallflowered, autogamous species or cleistogamous flowers has been shown to be associated with reduced rates or durations of floral development (Lord \& Hill, 1987; Guerrant, 1988; Hill et al., 1992).

*Correspondence and current address: Department of Botany, University of Maryland, College Park, Maryland 20742-5815, U.S.A.

†Current address: Department of Environmental, Population and Organismic Biology, University of Colorado, Boulder, CO 303090334, U.S.A.
Darwin's (1859) conclusion that evolution is a gradual process is reflected in the neo-Darwinian view that morphological differences of the kind that distinguish species are an extension of the variation found within and among populations (Fisher, 1958; Wright, 1968, 1978; Charlesworth et al., 1982). Therefore a question of considerable interest is, do simple changes in rates and timing of development associated with the evolution of complex adaptations also reflect a simple genetic basis due to major gene control (Goldschmidt,1940; Eldredge \& Gould, 1972; Gottlieb, 1984, 1985; Coyne \& Lande, 1985; Orr and Coyne, 1992)? Alternatively, do the relatively discontinuous character states induced by such changes reflect evolution at many loci?

Arguments for a simple genetic basis underlying large morphological changes in plants have emphasized the less complex developmental processes of plants compared to animals (Gottlieb, 1984). According to this view genes affecting development have relatively minor pleiotropic consequences and developmental traits are considered relatively independent of one another. Since the adult phenotype results from the interaction of various developmental processes, the degree to which these processes are genetically independent of one another will determine the con- 
straints to character evolution (Lande \& Arnold, 1983; Slatkin, 1987).

Here we examine the genetic basis of differences between floral growth parameters in two species of Monkey Flower (Mimulus - Scrophulariaceae). Floral architecture in these two species differs dramatically: large-flowered $M$. guttatus DC has a high pollen-ovule ratio and is herkogamous (large distance separating stigmas and anthers), whereas small-flowered $M$. micranthus Heller lacks herkogamy, is autogamous and invests relatively little in floral display or pollen production (Ritland \& Ritland, 1989). These differences in flower size are associated with contrasting mating systems in the two species. Outcrossing rates in $M$. guttatus populations range from 0.6 to 0.9 , while in $M$. micranthus populations they are much lower, averaging 16 per cent (Ritland \& Ritland, 1989). Isozyme and cpDNA data presented in Fenster \& Ritland (1992) are also consistent with the patterns of progenitor-derivative species-pairs outlined by Gottlieb $(1973,1977,1981)$ and suggest that $M$. micranthus is recently derived from $M$. guttatus. Mimulus micranthus contains only a subset of the allelic variation found within $M$. guttatus and for all loci the presumed derivative $M$. micranthus is either fixed or polymorphic for the most common alleles of $M$. guttatus. In addition, some $M$. guttatus populations have more cpDNA mutations in common with $M$. micranthus than they do with other M. guttatus populations.

Taking advantage of the cross-compatibility of $M$. guttatus with $M$. micranthus, our goal was to evaluate whether differences in the mating system associated with flower size in Mimulus are due to differentiation at many gene loci controlling floral develoment. Specifically we address the following two questions. (1) Is the duration and rate of bud elongation in large-flowered $M$. guttatus different from that in small-flowered $M$. micranthus, and if so, is this difference controlled by few or many genes? (2) Do the gene(s) affecting these developmental parameters act independently?

\section{Materials and methods}

\section{Study organisms}

Mimulus guttatus and M. micranthus (Scrophulariaceae, section Simiolus) are annual, self-compatible species found in moist, open habitats such as stream edges and ephemeral pools in western N. America. The large-flowered Mimulus guttatus has an extensive distribution whereas the small-flowered $M$. micranthus is limited to the coast ranges of central California (Munz \& Keck, 1973). Seed families of M. guttatus were collected from a particularly large-flowered population at Pt. Reyes, Marin Co., California and those of $M$. micranthus were collected from a population near Bartlett Springs, Lake Co., California.

\section{Crossing design and measurements}

Reciprocal pollinations were conducted between emasculated plants of $M$. guttatus and $M$. micranthus. $F_{1}$ progeny were verified using electrophoresis by detection of heterozygotes from parents fixed for alternative alleles. $F_{2}$ progeny were produced by crosses between $F_{1}$ individuals from different parents, thereby minimizing the effect of inbreeding depression on the expression of traits. Because crosses using $M$. micranthus as either a maternal parent or pollen donor were difficult to make, the $F_{1}$ was backcrossed only to $M$. guttatus. Parental $(N=20,22$ for $M$. micranthus, and $M$. guttatus, respectively), $\mathrm{F}_{1}(N=41), \mathrm{BC}(N=53)$ and $\mathrm{F}_{2}(N=140)$ generations were grown in a single experiment under uniform conditions in order to minimize the effects of environmental variation on floral traits. Plants were grown in $5 \mathrm{~cm}$ pots, at $18^{\circ} \mathrm{C}$ (daytime) and $14^{\circ} \mathrm{C}$ (night-time) under $18 \mathrm{~h}$ days.

One bud on each plant was marked by placing a spot of acrylic paint on the subtending leaf. This bud was measured daily with a calibrated wire (buds $<5 \mathrm{~mm}$ ) or digital caliper (buds $>5 \mathrm{~mm}$ ) until the corolla was fully expanded and anthers had dehisced. Bud length was measured as the distance from the receptacle to the corolla tip. Duration of bud development is defined as the number of days for a bud to elongate from the time the organs first became large enough to measure $(2$ $\mathrm{mm}$ ) to complete corolla expansion. Rate of bud development was measured as the slope of the regression of log transformed bud length plotted against days of growth. Only flower buds at the first five nodes on the primary (main) inflorescence were considered. No association of node position with either of the traits was observed within the first five nodes $(b=-0.03$, $t_{33}=0.464, P=0.65 ; b=0.0004, t_{33}=0.453, P=0.65$, regression of duration and rate on node number, respectively).

\section{Statistical analysis}

The segregational variance observed in the $F_{2}$ is directly associated with the number of factors responsible for differentiating the two parental taxa. The $F_{2}$ variance has two components: variance associated with the segregation of genes $\left(\sigma_{s}^{2}\right)$ and variance due to environmental factors. Because the parental generation and $F_{1}$ are assumed to be genetically uniform, any variance they exhibit may be assumed to be due to 
environmental effects. Sampling several genotypes from each parental species may have introduced some genetic variation into the parental and $F_{1}$ generations. However, the measured traits, duration and rate of bud elongation of the two parental species, differed by approximately nine and four standard deviations, respectively (the square-root of the mean phenotypic variance of the two parental species). Hence any within-species genetic variation should be only a small fraction of the variation differentiating the two taxa. Polygenic inheritance will be associated with smaller $\sigma_{\mathrm{s}}^{2}$ compared with the case where single or few genes are segregating during meiosis of the $F_{1}$ generation.

From the means and variances of parental and segregating generations the minimum number of factors (gene loci) differentiating the two taxa was estimated with a derivation of the procedure of Wright (1968) and Lande (1981) with its correction (Cockerham, 1986). A model for the estimation of gene number incorporating estimates of dominance based upon the segregating generation (as opposed to the $F_{1}$ ) was used (Fenster \& Ritland, 1994). Statistical gene counting methods are dependent on the experimental design to partition variance of the $F_{2}$ due to the segregation of loci in the $F_{1}$ from purely environmental sources of variation. Instead of simply extracting the $F_{1}$ variance or a weighted average of the parental and $F_{1}$ variance from the $F_{2}$ to determine the segregation variance (c.f. Lande, 1981) we used the method of Fenster \& Ritland (1994). This uses a fitted regression of the squared deviations of individual observations from their means on their means $\left(\mathrm{P}_{1}, \mathrm{~F}_{1}\right.$ and $\left.\mathrm{P}_{2}\right)$. The fitted regression was then used to predict expected environmental variance at the observed $F_{2}$ and mean values. Even if there is no dependence of variance upon the mean, this procedure is most efficient at extracting information about variance, but assumes linearity of dependence of the variance upon the mean.

A joint scaling test (program written by J. Shore, York University, Toronto, Ontario) was used to determine the relative contributions of additive and nonadditive gene action (Mather \& Jinks, 1982). Lack of backcrosses to the selfing species allowed us to test only a subset of the genetic components. In addition, the percentage of plants flowering and producing fertile flowers among the parental and $F_{2}$ generations was measured to determine the presence of hybrid breakdown and hence the action of epistasis.

Genetic correlations (equivalently, the proportion of genetic factors in common between a pair of traits) were estimated as the segregation covariance in the $\mathrm{F}_{2}$ (Humphreys \& Nicholls, 1984) divided by the geometric mean of the segregational variance of the two traits.
We encountered two statistical problems in the determination of the genetic basis of development rate. First, the variance of rate was based on the variance of the regressions of bud length on time. Because $M$. guttatus has the longer duration of bud development and $M$. micranthus the shorter, we had different degrees of freedom associated with the regressions of bud length on time for each of the generations. Thus, we observed a spurious relationship between duration of development and variance of rate, with the variance increasing with decreasing duration of development. Secondly, there is an inherent bias towards recovering a negative correlation between rate (length 2-length 1) $\left(\right.$ time $^{-1}$ ) vs. duration (time). Almost all buds had at least six days of measurements. By restricting our measurement of rate to measuring bud elongation over the first six days of measurement, we were able to factor out the role of sampling variance in the partitioning of environmental from segregational sources of variation in rate of bud elongation. Using the first six days of measurement also converted time to a constant and removed the spurious relationship between rate and duration.

\section{Determination of statistical error}

Formulae for the variances of estimates derived by Taylor series approximations, such as those given for gene number by Lande (1981) and for genetic correlations by Falconer (1981), substantially underestimate the actual variance (Zeng et al., 1990). Error terms are neglected, and in addition, the skewness of the error distribution is approximated as symmetrical. To include these additional features of error, we adopted the bootstrap method (Efron \& Gong, 1983) to estimate error. In our study, we are interested in the minimum estimate of gene number, thus the lower 5.0 percentile of the distribution of 1000 bootstrap estimates provides our lower bound estimate. For the genetic correlations we provide 95 per cent confidence intervals based upon the 2.5 and 97.5 percentiles of the distribution of 1000 bootstrap estimates.

\section{Results}

Mimulus micranthus has both a faster rate and a shorter duration of bud growth compared to $M$. guttatus (Table 1 and Fig. 1). The distributions of the two developmental parameters for each of the five generations are presented in Figs $1-3$. The $F_{1}$ progeny are approximately intermediate between either parental species and there is little overlap of the $F_{2}$ with 
Table 1 Means and variances of rate and duration of bud elongation for the five generations of crosses involving Mimulus micranthus and $M$. guttatus compared under uniform growth chamber conditions

\begin{tabular}{lrlrl}
\hline Generation & $\begin{array}{c}\text { Mean and variance of duration } \\
\text { of bud development } \\
\text { (days to anthesis) }\end{array}$ & $\begin{array}{c}\text { Mean and variance of rate of } \\
\text { bud development } \\
\text { (log(bud length/day)) }\end{array}$ \\
\hline M. micranthus & 5.3 & 0.1965 & 0.1484 & 0.000285 \\
$M$. guttatus & 11.2 & 0.6159 & 0.1020 & 0.000044 \\
$\mathrm{~F}_{1}$ & 7.7 & 0.4351 & 0.1317 & 0.000111 \\
$\mathrm{BC}$ to $M$. guttatus & 9.6 & 0.5320 & 0.1142 & 0.000154 \\
$\mathrm{~F}_{2}$ & 8.4 & 0.5729 & 0.1227 & 0.000127 \\
\hline
\end{tabular}

either parental type. Based on comparisons of progeny from reciprocal crosses, maternal effects were not observed for either duration $\left(t_{25}=0.02, P>0.90\right)$ or rate of bud elongation $\left(t_{31}=0.52, P>0.60\right)$. There is significant dominance for rate $\left(h=0.65, t_{40}=3.9\right.$, $P<0.001)$ and duration of bud elongation $(h=0.41$, $\left.t_{40}=5.1, P<0.001\right)$ with $M$. micranthus loci dominant over $M$. guttatus $\left[h=\left(\mathrm{F}_{1}-\mathrm{P}_{1}\right) /\left(\mathrm{P}_{1}-\mathrm{P}_{2}\right)\right.$ and is equal to 0.50 for the case of no dominance]. The loci differentiating $M$. micranthus from $M$. guttatus are, nonetheless, mostly additive in effect. Dominance is 30 per cent of its maximum possible value, $(h-0.5) / 0.5$, for bud elongation rate and 20 per cent of its maximum for duration of bud elongation.

The number of segregating factors differentiating $M$. micranthus from $M$. guttatus is 8.5 (lower bound of 95 per cent confidence interval $=3.2$ ) and 10.3 (lower bound of 95 per cent confidence interval $=4.6$ ) for growth rate and duration of bud development, respectively. There was no significant increase in the variance from the $F_{1}$ to the $F_{2}$ generations for either rate $\left(F_{40,139}=1.147, \quad P>0.25\right)$ or duration $\left(F_{40,139}=\right.$ $1.317, P>0.10)$ of bud development.

The joint scaling test revealed significant deviations from an additive-dominance model for both rate $\left(\chi_{2}^{2}=12.7, \quad P<0.005\right)$ and duration $\quad \chi_{2}^{2}=21.0$ $P<0.001)$ of bud development, implying that epistatic interactions among the loci influence the two developmental parameters. The interactions that we could detect demonstrated that the contribution of epistatic interactions was small, being either less than or equal in magnitude to dominance effects. In addition, little difference in the percentage of plants flowering and producing fertile flowers among the parental (mean $=90$ per cent) and $F_{2}$ generations (mean $=87$ per cent) was observed.

The genetic correlation of duration with rate of bud development was small, 0.16. However, the confidence intervals around our estimate were large, $-0.91 \pm 0.87$.
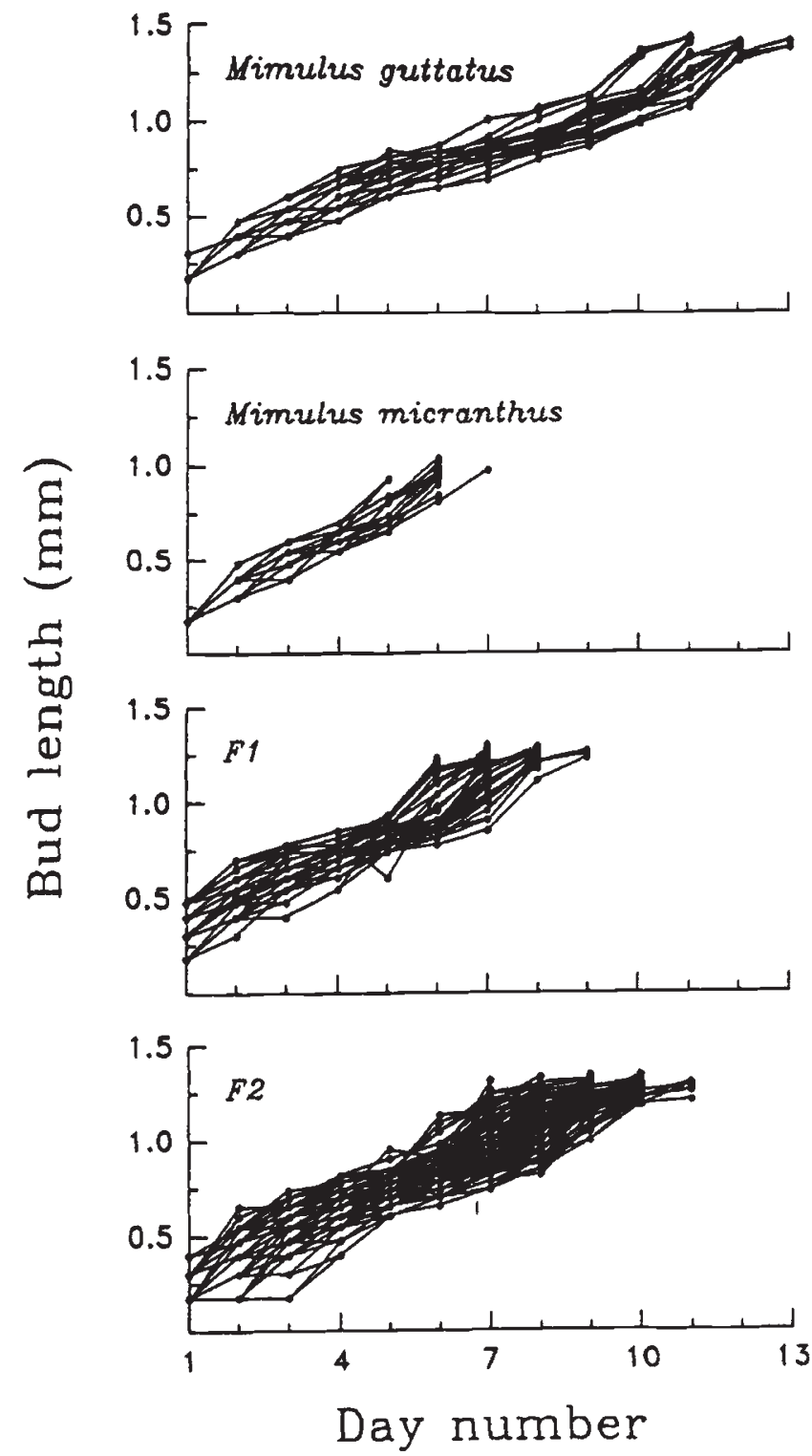

Fig. 1 The relationship between bud length (log scale) and days of growth for Mimulus micranthus, M. guttatus, and their $F_{1} s$ and $F_{2} s$. 

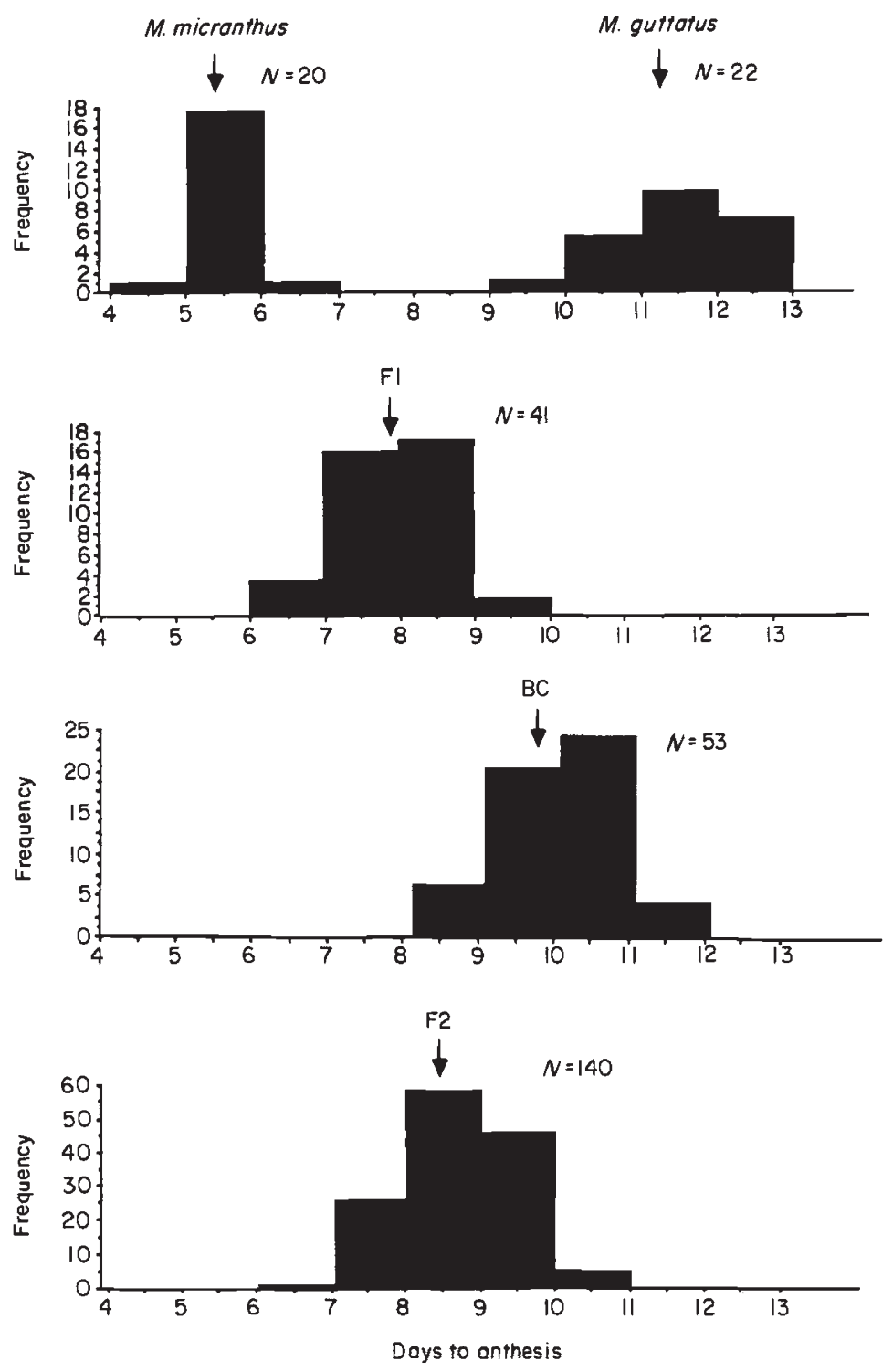

Fig. 2 Distribution of duration of floral elongation among Mimulus guttatus and M. micranthus, and the $\mathrm{F}_{1}$, $\mathrm{BC}$, and $\mathrm{F}_{2}$ generations. Means are designated by arrows. $N$ indicates the number of flowers measured.

\section{Discussion}

Genetic analysis of mature flower size among species of Mimulus indicates that the differences observed result from differences at many loci (Macnair \& Cumbes, 1989; Fenster \& Ritland, 1994). Studies presented here suggest that two developmental parameters which affect mature flower size, namely rate and duration of bud development, are also inherited in a quantitative fashion. No evidence was obtained to indicate that major genes (sensu Gottlieb, 1984, 1985) control heterochronic developmental processes in Mimulus species. The evolution of small flower size in $M$. micranthus is associated with both a shorter duration of floral development and more rapid floral growth. However, these characters show little genetic correlation with one another which suggests that both characters evolved independently of one another.

Few previous studies have investigated the genetic basis of divergence in reproductive traits expressed early in development. Goodwin (1944) observed that many loci differentiated races of Solidago sempervirens differing in time of appearance of floral bud primordia and duration of bud development, two characters which determined flowering time across a north-south latitudinal transect. Differences among species of Nicotiana in corolla size and shape are polygenic (East, 1916) and Smith (1950) concluded that the ratio of corolla limb and tube length in the bud and the relative rate of elongation of these two characters are also under polygenic control in this genus. In contrast, Sinnott $(1935,1936)$ and Kaiser (1935) observed that 

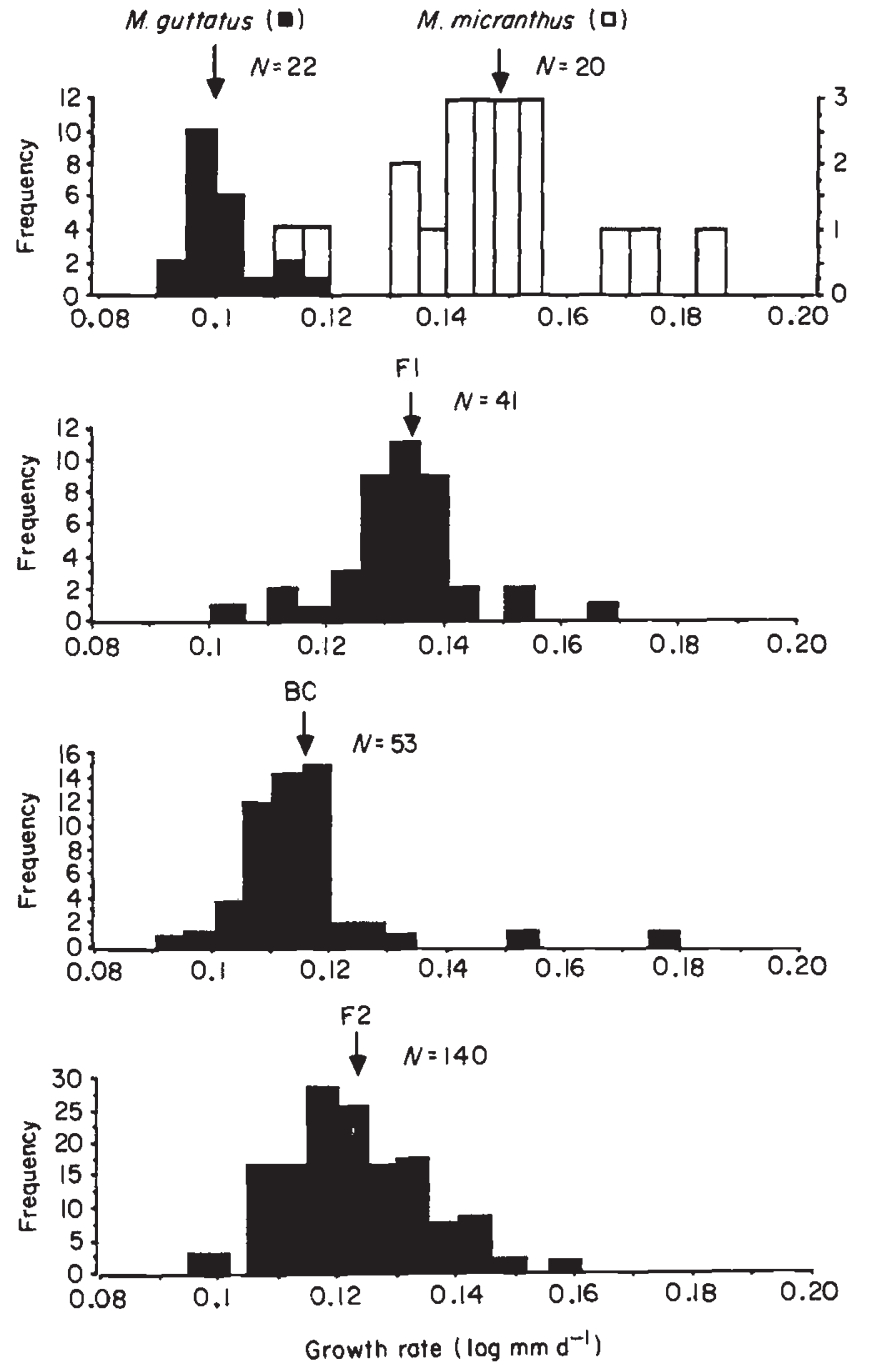

Fig. 3 Distribution of rate of floral elongation among Mimulus guttatus and M. micranthus, and the $\mathrm{F}_{1}, \mathrm{BC}$, and $\mathrm{F}_{2}$ generations. Means are designated by arrows. $N$ indicates the number of flowers measured. Note that the parental generations, $M$. guttatus and $M$. micranthus, are plotted on different scales.

few genes of major effect (also controlling relative growth rates) were responsible for large shape differences between fruits of domesticated lines of Cucurbita and Capsicum. More recently, Doebley \& Stec $(1991,1993)$ provided evidence that key morphological traits differentiating maize and teosinte were influenced by specific regions of the chromosomes, suggesting the role of major genes as well as many modifier genes. However, differentiation among the domesticated lines of Curcurbita, Capsicum and maize may represent the action of strong artificial selection or selection of single gene mutants resulting in the fixation of genes of major effect (Lande, 1983). Although
Gottlieb (1984) cited a number of examples of morphological differences among species that are controlled by one or two genetic factors, differences in floral morphology associated with mating-system variation are frequently due to genetic differences at many loci (e.g., Shore \& Barrett, 1990; Holtsford \& Ellstrand, 1992; but see Marshall \& Abbott, 1982).

We observed incomplete dominance for the alleles contributed by the small-flowered, autogamous $M$. micranthus. Incomplete dominance is observed for many quantitative traits (Falconer, 1981) and is further evidence against the role of major gene control in trait differentiation (Kacser \& Burns, 1981). Intermediate $F_{1}$ values suggest that selection on variation maintained in $M$. guttatus populations is responsible for the trait differences between the two taxa (Charlesworth, 1992).

We estimated that the numbers of genetic factors differentiating $M$. guttatus from $M$. micranthus for growth rate and bud development were 8.5 and 10.3 factors, respectively. Although the number of segregating factors calculated by Wright's (1968) and Lande's (1981) procedure and our derivative method (Fenster \& Ritland, 1994) is not precise, the methods do provide a minimum estimate of the number of factors differentiating the two species. The estimate obtained often does not exceed the number of chromosomal segments segregating in one generation $(n=14$ for $M$. guttatus, Vickery, 1978; Zeng et al., 1990). Variation of allelic effects will also decrease the estimate of the number of genetic factors, and nonadditive gene effects may either increase or decrease the estimate of gene differences (Mather \& Jinks, 1982), but should be small compared to the effects of linkage (Zeng et al., 1990).

The nonsignificant increase in variation from the $F_{1}$ to the $F_{2}$ generation for the two developmental parameters supports the conclusion that the number of factors differentiating the two species is relatively large. The lack of increase implies that the segregation variance is essentially zero compared to the environmental variance and that the number of genetic factors differentiating the two taxa is large. This result would not occur if there were major genes controlling floral development in the two species. Note that larger sample sizes would not have led to an increase in the segregation variance, and hence a smaller estimate of the number of factors differentiating the two species. The differences between the $F_{1}$ and $F_{2}$ variances were so small that even increasing the $F_{2}$ sample size to infinity would not have resulted in a significant $F$ ratio. The relatively large variation observed for the two developmental traits in the parental and $F_{1}$ generations also underscores the large contribution made by environmental effects to these traits. 
The observation of little correlation between the two developmental parameters is robust to the expectation of observing a spurious correlation due to linkage disequilibrium. This should be high in a cross between two species with the assumption that all genes differentiating the species are fixed for opposite alleles. Thus, the negative association of duration and rate of bud elongation across the two parental species (short duration and high rate in $M$. micranthus and long duration and slower rate in $M$. guttatus) could have generated a negative genetic correlation in the segregating $\mathrm{F}_{2}$ which could have mistakenly been identified as pleiotropic gene action. Little correlation between the two developmental traits has two consequences. First, it suggests that small flowers may result from changes in either developmental parameter. This is in accord with most models of heterochrony which include rate and duration of development as independent variables (Gould, 1977) and morphological change as the result of independent evolution of these two variables. Secondly, little correlation implies that different loci are responsible for the differentiation of the two traits across the two species. This result reemphasizes that the differentiation of flower size between the two species is due to many loci but must be interpreted with caution because of the imprecision of the estimates.

An understanding of the developmental basis of flower size differences in Mimulus may provide information on the evolutionary mechanisms responsible for the evolution of selfing. Gould (1977) has suggested that truncation of ontogeny may be associated with strong selection for rapid maturation. If genes affecting duration of bud development have little pleiotropic effects on rate of bud development, or vice versa, then the present developmental processes responsible for smaller flower size in $M$. micranthus may be due to selection favouring both shorter duration and more rapid rate of bud development (Fig. 1). Rapid floral development may be favoured in ecologically or geographically marginal environments (Guerrant, 1988), and by bet-hedging in variable environments (Ritland \& Jain, 1984). Several days of pollinator visits are necessary before full seed-set is ensured for a $M$. guttatus flower under native conditions (Dudash \& Ritland, 1991). In contrast, $M$. micranthus stigmas are covered with pollen just prior to or simultaneous with flower opening (personal observation). Furthermore, under field and greenhouse conditions $M$. micranthus flowers earlier than $M$. guttatus (Fenster \& Ritland, 1994). In total, these results suggest that small flower size and self-fertilization have evolved in $M$. micranthus as a response to selection for rapid development. Note that this does not imply that the evolution of loss of herkogamy and selfing in $M$. micranthus is simply a correlated response to selection for rapid development and flower size. Elsewhere (Carr \& Fenster, 1994; Fenster \& Ritland, 1994), we have demonstrated little genetic correlation of stigma-anther separation distance with flower size or date of first flower in Mimulus. In addition, Macnair \& Cumbes (1989) also failed to observe a correlation between flowering time and vegetative development in crosses between different Mimulus species. These results suggest that the evolution of selfing may reflect direct selection on mating system and that the evolution of selfing represents an additional evolutionary mechanism of reducing the life cycle. However, the evolution of small, autogamous flowers need not reflect a decreased duration of development but may result from a decreased rate of ontogeny, e.g. Arenaria (Hill et al., 1992). Rather than reflecting selection for rapid development, selfing in this group may have evolved in response to competition for pollinators (Wyatt, 1988).

The advantage of determining the genetic basis of trait differentiation by interspecific crosses is that it provides a direct estimate of the minimum number of genes without having to extrapolate from withinspecies studies. For example, developmental mutants of large and epistatic effect are sometimes observed by developmental biologists and have been elegantly used to clarify processes of floral development (e.g., Schwarz-Sommer et al., 1991). Other within-species studies have revealed that single gene mutations are responsible for changes in timing and rates of development in nematodes (Ambros, 1988) and tomato floral characters (Sawhney, 1992). It may be difficult, however, to extrapolate these findings to between-taxa differences (Coyne \& Lande, 1985) since genes of major effect often have large negative pleiotropic consequences, e.g., major genes may be involved in the differentiation of maize from its teosinte ancestors but maize, like many other domesticated species, is unable to reproduce without extreme human manipulation of the environment.

Major gene control of floral development, as discussed above, is more likely to be associated with epistatic gene action. Thus lack of evidence for epistasis is also supportive of a polygenic differentiation between $M$. micranthus and $M$. guttatus. The number of factors differentiating the developmental patterns of the two Mimulus species appears to be large. Hence the proportion of the difference explained by any gene is small and the likelihood of epistasis being important is diminished (Wright, 1968). The small magnitude of the epistatic effects from the joint scaling test and little difference in plants flowering and producing fertile flowers among the parental and $F_{2}$ generations further 
suggest that epistatic contributions by genes having large genetic background effects have probably not been important to mating-system evolution in Mimulus. Similar results have been observed by Macnair \& Cumbes (1989) in their study of the genetic basis of species differences between the smallflowered, self-fertilizing species Mimulus cupriphilus and $M$. guttatus. The evolution of small flowers in $M$. micranthus has arisen through heterochrony via shortening the duration of bud elongation. Although this relatively simple change in developmental process has resulted in major morphological differences between species, the genetic basis underlying floral evolution is not due to changes of a single major gene but rather, reflects evolution at many loci.

\section{Acknowledgements}

This research was funded by NSERC operating grants to K. Ritland and S. C. H. Barrett. J. Shore kindly provided a computer program for the joint scaling test. Comments by D. Carr, M. Macnair, T. McLellan, and B. Mishler improved the manuscript.

\section{References}

AMBRos, v. 1988. Genetic basis for heterochronic variation. In: McKinney, M. L. (ed.) Heterochrony in Evolution, pp. 269-285. Plenum Press, New York.

CARR, D. E. AND FENSTER, C. B. 1994. Levels of genetic variation and covariation for Mimulus (Scrophulariaceae) floral traits. Heredity, 72, 606-618.

CHARLESWORTH, B. 1992. Evolutionary rates in partially selffertilizing species. Am. Nat., 140, 126-148.

CHARLESWORTH, B., LANDE, R. AND SLATKIN, M. 1982. A neoDarwinian commentary on macroevolution. Evolution, 36, 474-498.

COCKERHAM, C. C. 1986. Modifications in estimating the number of genes for a quantitative character. Genetics, 114, 659-664.

COYNE, J. A. AND LANDE, R. 1985. The genetic basis of species differences in plants. Am. Nat., 126, 141-145.

DARWIN, c. 1859. On the Origin of Species, 1st edn. John Murray, London. (Reprinted 1964, Harvard University Press, Cambridge, MA).

DIGGLE, P. K. 1992. Development and the evolution of plant reproductive characters. In: Wyatt, R. (ed.) Ecology and Evolution of Plant Reproduction: New Approaches, pp. 326-355. Chapman and Hall, New York.

DOEBLEY, J. AND STEC, A. 1991. Genetic analysis of the morphological differences between maize and teosinte. Genetics, 129, 285-295.

DOEBLEY, J. AND STEC, A. 1993. Inheritance of the morphological differences between maize and teosinte: comparison of results for two $\mathrm{F}_{2}$ populations. Genetics, 134, 559-570.
DUDASH, M. R. AND RITLAND, K. 1991. Multiple paternity and self-fertilization in relation to floral age in Mimulus guttatus (Scrophulariaceae). Am. J. Bot., 78, 1746-1753.

EAST, E. M. 1916. Studies on size inheritance in Nicotiana. Genetics, 1, 164-176.

EFRON, B. AND GONG, G. 1983. A leisurely look at the bootstrap, the jackknife and cross-validation. Am. Statist., 37, 36-48.

ELDREDGE, N. AND GOULD, S. J. 1972. Punctuated equilibria: an alternative to phyletic gradualism. In: Schopf, T. J. M. (ed.), Models in Paleobiology, pp. 82-115. Freeman, Cooper and Co., San Francisco.

FALCONER, D. S. 1981. Introduction to Quantitative Genetics, 2nd edn. Longman, London and New York.

FENSTER, C. B. AND RITLAND, K. 1992. Chloroplast DNA and isozyme diversity in two Mimulus species (Scrophulariaceae) with contrasting mating systems. Am. J. Bot., 79, 1440-1447.

FENSTER, C. B. AND RITLAND, K. 1994. The quantitative genetics of mating system divergence in the yellow monkeyflower species complex. Heredity, 73, 422-435.

FISHER, R. A. 1958. The Genetical Theory of Natural Selection. Dover Publications, New York.

GOLDSCHMidT, R. B. 1940. The Material Basis of Evolution. Yale University Press, New Haven, CT.

GoodWIN, R. H. 1944. The inheritance of flowering time in a short-day species, Solidago sempervirens. Genetics, 29, 503-519.

GOTTLEB, L. D. 1973. Genetic differentiation, sympatric speciation, and the origin of a diploid species of Stephanomeria. Am. J. Bot., 50, 545-553.

GOTTLIEB, L. D. 1977. Electrophoretic evidence and plant systematics. Ann. Mo. Bot. Gard., 64, 161-180.

GOTTLIEB, L. D. 1981. Electrophoretic evidence and plant populations. In: Reinhold, L., Harborne, J. B and Swain, T. (eds) Progress in Phytochemistry, vol. 7, pp. 1-46. Pergamon, Oxford.

GOTTLIEB, L. D. 1984. Genetics and morphological evolution in plants. Am. Nat., 123, 681-709.

GoTTlieb, L. D. 1985. Reply to Coyne and Lande. Am. Nat., 126, 146-150.

Gould, s. J. 1977. Ontogeny and Phylogeny. Harvard University Press, Cambridge, MA.

Gould, s. J. 1988. The uses of heterochrony. In: McKinney, M. L. (ed.) Heterochrony in Evolution, pp. 1-13. Plenum Press, New York.

GUERRANT, E. O., JR. 1988. Heterochrony in plants: The intersection of evolution, ecology and ontogeny. In: McKinney, M. L. (ed.), Heterochrony in Evolution, pp. 111-133. Plenum Press, New York.

HILL, J. P., LORD, E. M. AND SHAW, R. G. 1992. Morphological and growth rate differences among outcrossing and self-pollinating races of Arenaria uniflora (Caryophylaceae). J. Evol. Biol., 5, 559-573.

HOLTSFORD, T. P. AND ELlSTRAND, N. C. 1992. Genetic and environmental variation in floral traits affecting outcrossing rate in Clarkia tembloriensis (Onagraceae). Evolution, 46, 216-225.

HUMPHREYS, M. O. AND NICHOLLS, M. K. 1984. Relationships between tolerance to heavy metals in Agrostis capillaries 
(= A. tenuis Sibth.). New Phytol., 98, 177-190.

KACSER, H. AND BURNS, J. A. 1981. The molecular basis of dominance. Genetics, 97, 639-666.

KAISER, S. 1935. The factors controlling shape and size in Capsicum fruits; a genetic and developmental analysis. Bull. Torrey Bot. Club, 62, 433-454.

LANDE, R. 1981. The minimum number of genes contributing to quantitative variation between and within populations. Genetics, 99, 541-553.

LANDE, R. 1983. The response to selection on major and minor mutations affecting a metrical trait. Heredity, 50, 47-65.

LANDE, R. AND ARNOLD, S. J. 1983. The measurement of selection on correlated characters. Evolution, 37, 1210-1226.

LORD, E. M. AND HILL, J. P. 1987. Evidence for heterochrony in the evolution of plant form. In: Raff, R. A. and Raff, E. C. (eds) Development as an Evolutionary Process, pp. 47-70. Alan R. Liss, New York.

MACNAIR, M. R. AND CUMBES, Q. J. 1989. The genetic architecture of interspecific variation in Mimulus. Genetics, 122, 211-222.

MARSHALL, D. F. AND ABBoTt, R. J. 1982. Polymorphism for outcrossing frequency at the ray floret locus in Senecio vulgaris L. I. Evidence. Heredity, 48, 227-235.

MATHER, K. AND JINKS, J. L. 1982. Biometrical Genetics, 3rd edn. Chapman and Hall, London.

MUNZ, P. A. AND KECK, D. D. 1973. A California Flora and Supplement. University of California Press, Berkeley and Los Angeles.

ORR, H. A. AND COYNE, J. A. 1992. The genetics of adaptation: a reassessment. Am. Nat., 140, 725-742.

RITLAND, K. AND JAIN, S. 1984. The comparative life histories of two annual Limnanthes species in a temporally variable environment. Am. Nat., 124, 656-679.

RITLAND, C. AND RITLAND, K. 1989. Variation of sex allocation among eight taxa of the Mimulus guttatus species complex. (Scrophulariaceae). Am.J. Bot., 76, 1731-1739.

SAWHNEY, V. K. 1992. Floral mutants in tomato: development, physiology, and evolutionary implications. Can. J. Bot., 70, 701-707.

SCHWARZ-SOMMER, Z., HUIJSER, P., NACKEN, W., SAEDLER, H. AND SOMMER, H. 1991. Genetic control of flower development by homeotic genes in Antirrhinum majus. Science, 250 , 931-936.

SHORE, J. S. AND BARRETT, S. C. H. 1990. Quantitative genetics of floral characters in homostylous Turnera ulmifolia var. angustifolia Willd. (Turneraceae). Heredity, 64, 105-112.

SINNOTT, E. W. 1935. Evidence for the existence of genes controlling shape. Genetics, 20, 12-21.

SINNOTT, E. W. 1936. A developmental analysis of inherited shape differences in Cucurbit fruits. Am. Nat., 70, 245-254.

SLATKIN, M. 1987. Quantitative genetics of heterochrony. Evolution, 41, 799-811.

SMITH, H. н. 1950 . Developmental restrictions on recombinations in Nicotiana. Evolution, 4, 202-211.

TAKHTAJAN, A. 1976. Neoteny and the origin of flowering plants. In: Beck, C. B. (ed.) Origin and Early Evolution of Angiosperms, pp. 207-219. Columbia University Press, New York.

VICKERY, R. K. 1978. Case studies in the evolution of species complexes in Mimulus. Evol. Biol., 11, 405-507.

WRIGHT, s. 1968. Evolution and the Genetics of Populations, vol, 1, Genetic and Biometric Foundations. University of Chicago Press, Chicago.

WRIGHT, s. 1978. Evolution and the Genetics of Populations, vol. 4, Variability Within and Among Natural Populations. University of Chicago Press, Chicago.

WYATT, R. 1988. Phylogenetic aspects of the evolution of selfpollination. In: Gottlieb, L. D. and Jain, S. K. (eds) Plant Evolutionary Biology, pp. 109-131. Chapman and Hall, New York.

ZENG, Z.-B., HOULE, D. AND COCKERHAM, C. C. 1990. How informative is Wright's estimator of the number of genes affecting a quantitative character? Genetics, 126, 235-247. 